\title{
Health Promotion Strategy In Collaboration TB - HIV In Medan
}

\author{
R.Kintoko Rochadi ${ }^{1}$, Lina Tarigan ${ }^{2}$, Syarifah ${ }^{3}$, Maya Fitria ${ }^{4}$ \\ \{kintokorochadi2@gmail.com¹, linatarigan06@gmail.com², syarifah_usu@yahoo.com³, \\ mayafitria@gmail.com ${ }^{4}$. \\ ${ }^{1}$ Deparment of Health Education and Behavioral Sciences, University of North Sumatra, \\ Medan, Sumatera Utara, Indonesia \\ ${ }^{2}$ Department Occupational and Health Safety, University of North Sumatra Medan, Sumatera Utara, \\ Indonesia \\ ${ }^{3}$ Deparment of Health Education and Behavioral Sciences, Medan, Sumatera Utara, Indonesia \\ ${ }^{4}$ Deparment of Biostatistic and population, University of North Sumatra, Medan, Sumatera Utara, \\ Indonesia
}

\begin{abstract}
Tuberculosis (TB) is still a public health problem in the world. The global challenge that needs attention now is TB-HIV. The targets are TB Patients who know the status of HIV in 2016 is $45 \%$ and $85 \%$ in 2017 . The informant's qualitative research method was the manager of the TB program in the Health Office of North Sumatra Province and Medan City, the implementers of the TB-HIV program at the Medan City Health Center and an NGO engaged in HIV Prevention. Data were collected through in-depth interviews and focus group discussions (FGD), Analyzed descriptively. The results of the study concluded that coordination of health services has been established but the TB-HIV collaboration has not been maximized. Therefore, promotion strategies include advocacy, program communication and social mobilization and community empowerment so that TB-HIV collaboration in Medan Reaches the targets set.
\end{abstract}

Keywords: Health promotion strategies, Collaboration, TB-HIV.

\section{Introduction}

Two of the global challenges that need attention now is Tuberculosis (TB) and HIV (Human Immunodeficiency Virus Epidemic). TB-HIV shows an influence on the increasing TB epidemic throughout the world, that resulted in an increasing number of cases of TB in the community. Much evidence suggests that TB control will not work well without the successful control of HIV. Likewise, TB is one of the opportunistic infections that frequently occur and the main cause in people with HIV-AIDS (PLWHA). Collaboration between the two programs is essential to tackle these two diseases effectively and efficiently [1].

Ministry of Health Regulations No. 21 of 2013 on HIV AIDS and circular letter No. 129 of 2013, said HIV testing is recommended in patients with TB, and special populations such as pregnant women, STI patients, people living with HIV, Hepatitis, couples living with HIV negative as well as key populations (MSM, transvestite, IDU and sex workers). This strategy is implemented gradually until it reaches 75 SUFA District Municipality will apply in 2015 and is expected to all District / City is already implementing SUFA [2]. 
Although it has been issued Minister Regulation No. 74 of 2014 as the implementation of VCT on Initiation Health Officer (KTIP) when performed in TB patients without HIV risk, however, until 2012 the results of a cohort of MoH RI showed that only $2 \%$ of TB patients knew their HIV status and among them 33\% HIV positive [3]. The reality, more bigger in a community than the figure above, and of the TB patients HIV cases have not checked it for various reasons [4]. Medan is one of the pilot cities project collaboration TB (TB-HIV). The expected target of TB cases who know her HIV status there in 2016 by $45 \%$, and $85 \%$ in 2017 . However, TB patients knew their HIV status in 2015 by $15 \%$ and increased to $24 \%$ in 2016 and are still smaller than the target set. One thing that is quite encouraging that TB patients who know their HIV status and receive ARV rise high enough (7\%) in 2015 to (47\%) in 2016. This data indicates if TB patient knows their HIV status then they will take ARVs which can ultimately improve his quality of life.

Low collaborative TB-HIV in Medan because not all DOTS services such as health centers provide HIV testing, or VCT, access to HIV testing limited, from 39 health centers, already have Kidney Transplantation (KT) HIV only 18 health centers, three health centers Care Support training (PDP) and only 12 Hospitals that already HIV Test Top Initiation Health and Counseling Officer (TIPK) and 18 Hospitals that already PDP. In this regard, it is necessary to study the health promotion strategy in the improvement of TB-HIV collaboration.

\section{Method}

This is the qualitative study of the chairman of the health North Sumatra Provincial Health Office ( P2P sector) and City Health Office of Medan and implementing PHC TB program. Collecting data from informants conducted through focus group discussions, observation and documentation. The data collection was initiated by the key informant interviews, officers Provincial Health Office and the city of Medan in particular sub-section of infectious diseases (TB) every 4 people. The interview then continued to implementers of TB programs at the Health Center Puskesmas Medan Belawan, Medan Helvetia, Medan Baru each of the health centers is 2, and NGOs working in HIV programs are also two people, the total informant is 12 people.

Before the FGD, each informant was given a verbal explanation of the purpose and objectives of the research. They were given an explanation in Indonesian that they participated in the study. They were also given an explanation that they can refuse to answer questions that do not want to answer. To all of them signed informed consent.

Interviews conducted by the principal investigator. Interviews were recorded by using a voice-recording. Data manually transcribed by the researcher and analyzed by content analysis. Before carrying out research conducted before obtaining a license from the research and from the USU Research Institute of the Ethics Committee of the Faculty of Nursing, University of North Sumatra.

\section{Result}

In connection with the issuance of the Decree of the Minister of Health of the Republic of Indonesia Number 1278 / Menkes / SK / XII / 2009 on the guidelines for the implementation of 
collaborative TB and HIV disease control. The general objective of this collaboration is to provide direction in the implementation of TB-HIV collaboration to reduce the burden of TB and HIV in the society due to the two diseases. With the special-purpose implementation of TBHIV collaboration through the establishment of the mechanism of TB-HIV collaboration, lowering the burden of TB in people living with HIV and lower the burden of HIV in TB patients.

The results showed already in the form of the mechanism of collaborative TB-HIV in the province of North Sumatra with POKJA TB-HIV, whose members consist of the Provincial Health Office of North Sumatra particularly TB Program, AIDS Program, MoHand Elements of Hospital and Health Center, Experts and Specialists TB and HIV, Professional organizations and NGOs. The task of this working group are; work plan, the person in charge of each activity TB and HIV and to determine its partners. Besides, the working group is also coordinating with the team DOTS, HIV and element management team as RS, Head of the Health Center, doctors, nurses, laboratory workers, Pharmaceutical Officer, Counselor, recording and reporting officer.

Each year has conducted a performance evaluation of TB-HIV collaboration by the provincial Health Department, but there are still many Kendal-obstacles encountered in achieving the goals set in the TB-HIV collaboration. In connection with the still not yet working mechanisms of collaboration then in September 2019 is based on the Letter Head of Health Department of North Sumatra Province No. 443.24 / 13621 / PHO / IX 2019 meetings were held Restructuring and Strengthening Working Group on TB-HIV North Sumatra Province with the aim of enabling the Working Group TB-HIV by forming areas in accordance with the guidelines set and each field discuss their respective work program to be followed up. It is expected that with this restructuration for TB-HIV Working Group will be run by its duties and functions

\section{Discussion}

\subsection{Health Promotion Strategy in increasing TB-HIV collaboration}

Advocacy is one of the strategies in health promotion, important advocacy carried out to improve TB-HIV collaboration. Advocacy is an approach to secure the economic resources and policy changes, by influencing stakeholders, the private sector, elements of society, including the media. During these health problems is considered only for the health of people belonging to address this problem needs to be done in collaboration with other stakeholders such as the department of education of middle and higher education level, Social Services, Department / Department of Religious Affairs, the Department of Tourism as the informant's narrative following health centers:

"Until 2019 August at our health centers there are \pm 356 HIV patients consisted of 166 men, 190 women, and of this $50 \%$ are special population groups, namely transvestites, IDUs, FSWs, MSM. Would that we nurture this special group advance than others "(informant puskesmas).

This particular group coaching are the main priorities that need to be addressed, the handling is certainly more appropriate to approach religion through religious leaders. Besides the role of Social Service in fostering this particular group is very important so how an advocacy strategy on Social Service. In connection with the advocacy of course, who has the authority not executing at the health center level but are the policymakers at the level of the Provincial Health 
Officer and the City Health Department. The results also showed that cooperation with stakeholders in the HIV response has long held that since the discovery of HIV, especially with HIV Aids Control Commission (KPADs) North Sumatra Province. Since the early development of the Commission on HIV / AIDS has been carrying out reinforcement in the form of training on religious leaders/community, society and build a network by setting up a District Level KPADs in cities in North Sumatra. But until now the HIV cases are still increasing, where the increase is more rapid in comparison while the transmission of TB TB easier.

KPADs indeed have a lot of work in HIV-AIDS, but until now the stigma and discrimination against HIV-TB remain high because there is no sustainability program, it describes by an informant that:

"That since KPADs not receiving anymore then KPA activity has weakened and regular meetings activity in the prevention of HIV-AIDS is rarely implemented due to funding limitations "(informant Health Service).

This study coincides with findings Mitsel et al (6) that advocacy of key stakeholders in the response and prevention of HIV / AIDS by KPADs and Department goes along with Health not good, there are no reports to key policymakers, making the weak support for the allocation of funds in efforts to prevent and tackle HIV / AIDS in Sorong Regency. Advocacy of key stakeholders namely KPADs and the Department should be more active Health is made to key stakeholders that make good policy to the executive (BAPPEDA) and legislative (parliament) for the effort to mitigate and prevent HIV / AIDS can be run with the maximum $[5]$.

Similarly, advocacy with the Department of Education needs to be done for people living with HIV in adolescents is increasing, while the informant:

in some schools still, the school would not be a place for reproductive health interventions, including HIV, according to the principal for the same course we teach the children for bad behavior (Informants health centers and NGOs).

Understanding of principals who have not had the impact on the level of health precisely in the children's understanding of HIV is still low and it is not surprising if the high adolescent HIV among others acquired through sexual intercourse. This is because the nature of teenagers wants to try and reality fact the field many teenagers to the Hotel, SPA and become customers PSK. Thus the expected educational institutions so spot reduces HIV stigma in society is not maximized, because there is much taboo to talk about reproductive health issues. Educational institutions should be instrumental in providing sex education to children according to age level. Refusal to talk about reproductive and sexual health issues among young people increasingly taboo especially over several schools with a religious background.

advocacy activities in the order contribute to TB control objectives including educating religious leaders of politics and representation, reform policies or laws or affect the mass deployment through media and media package journalist training, to stimulate additional power allocation of resources focused on TB control. Thus advocacy by WHO in Advocacy, Communication, Social Mobilization (AKMS) aims to secure the financial resources, changes in policies, guidelines or procedures to influence policies of stakeholders such as politicians, decision-makers and including journalists in Medan can be realized.

\subsection{Collaboration of NGOs}

The results showed that the internal and external network of TB-HIV in health care facilities already built but not maximized. Many NGO's referrals of TB patients tested for HIV and people living with HIV who are referred for TB examination could not be followed because of not 
optimal referrals between TB units and unit KTS / PDP. To do models FGD collaboration then performed as the following attachments:

"TB-HIV so actually it is already a package, then the related HIV data there are 4,323 people that our data in 2019 and HIV data for children is 202 children with HIV were also made our thinking. so today we are already working with 32 schools, then in collaboration with 9 media now ready to publish the activities we do today. To respond before what we do to reduce the rise in HIV and TB disease? "(Informers; LSM)

So that collaboration can be maximized then Communication is important to increase awareness, influence social norms, create behavioral change among individuals in society, and increase interpersonal communication and counseling among TB diseases with people, their families, and health service providers Poor understanding of HIV on TB and TB patients about HIV as well as in the family is still high stigma, TB patients who do not want to be known his wife and family status, the number of patients seeking treatment rather than the nearest health center is an example of cases that require communication to improve awareness and change norms and behavior in society.

\subsection{Community development}

Community empowerment in the promotion strategy in this study together with the WHO concept of the Social Mobilization AKSM. 2007A Schiavo (2014) explain the concept of community mobilization (community mobilization) and social mobilization (social mobilization) are two important and interrelated concepts in health communication. In community mobilization, the importance of community dialogue, self-reliance (confidence) in a participatory manner, both in theory and practice implementation. Community mobilization is a bottom-up and participatory process, through multiple communication channels, trying to involve community leaders and the public in dealing with health issues, is an important part of social and behavioral change, or practice the desired behavior social force for change. This concept is incorporated into the idea of social mobilization. Social mobilization is the process of bringing or unite together multi-sectoral community partners to raise awareness, needs, and progress for the purpose of the initiative process and results (Patel 2005 in Schiavo 2014),

Social mobilization means involving all elements of society, society so that it is possible to gather resources to conduct collective power and build solidarity to overcome the problem together. The strategy of advocacy, communication, and social mobilization are interrelated POINTS (Amiruddin et al 2014). Rocawear 2008 in Amiruddin et al (2018) concluded that in India AKMS increased strategy case detection and referral strong systems forming mechanism. The combination of advocacy, communication, and social mobilization approaches to improve the detection of TB cases. The social mobilization carried out in Medan already running where NGOs have been active in reaching high-risk groups commercial Sex Workers (CSWs), Men Sex Men (MSM), Transvestite, Injecting drug users(IDU) invites checked into the clinic, for the positive cases treated, for the negatives taken in order to change behavior. Already there are cadres to a positive case to want to seek treatment regularly. But for a group of high negative risk, no container can change their behavior into positive behavior [7]. This condition is highly coveted by an informant Health Center with the following narrative:

"for this approach is that we do more to focus on treatment and rehabilitation while forgetting the preventive and promotive approach to high-risk groups and have not been positive for HIV or TB" 
Kamineni et al (2011) research about advocacy, communication and mobilization TB control in India. The results showed collaboration Non-Government Organization (NGO) as an interface, coupled with increasing collaboration training and health and community groups, community-based resource deployment, contributed to the increased knowledge about TB. Jugamemberikan program activity contributes to health workers as effective in improving compliance treatment society. With the success of the patients in treatment also helps to reduce and the stigma and discrimination in society[6].

\section{Conclusion}

The results showed that TB patients know their HIV status is low because not all hospitals and clinics run the DOTS system. In each poly, RS stands alone. Although the clinics have been implementing DOTS system, not all TB patients HIV cases examined her, so not all TB patients knew their HIV status and not all health centers providing ARV.

Advocacy strategies TB - HIV in Medan not running optimally to secure the financial resources, changes in policies, guidelines or procedures to influence policy stakeholders, politicians, decision-makers and include journalists in Medan can be realized.

An internal and external network of TB-HIV in health care facilities already built but not maximized. Many TB patients and people living with HIV NGO referral for HIV testing for TB examination could not be followed because of not optimal referrals between TB units and unit KTS / PDP.

Community empowerment or social mobilization carried out in Medan is already running but is not maximized, because still, more on curative handlers have not been on promotive and preventive activities. NGOs have been active in reaching high-risk groups commercial Sex Workers (CSWs), Lelasi Sex Men (MSM), Transvestite, Injecting drug users (IDU) invites checked into the clinic, for the positive cases treated, for the negatives taken to change behavior. Already there are cadres to a positive case to want to seek treatment regularly. However, for the high-risk group with HIV-negative TB status has been no container that can change their behavior into positive behavior.

\section{References}

[1] Departemen Kesehatan RI. (2011). Pedoman Nasional Penanggulangan tubercullosis cetakan kedua. Jakarta

[2] Dinas Kesehatan Provinsi Sumatera Utara. 2018. Kebijakan Program Pengendalian TBC Provinsi Sumatera Utara. Medan

[3] Kementerian Kesehatan RI. 2014. Petunjuk Teknis Manajemen Terpadu Pengendalian Tuberklosis Resisten Obat. Direktorat Jenderal Pengendalian Penyakit dan Penyehatan Lingkungan. Jakarta.

[4] Mitsel. Mahendradhata, Y., Padmawati, R. (2015). Peran Stakeholder Kunci Dalam Kebijakan Penanggulangan Dan Pencegahan Hiv/Aids Studi Kasus Di Kabupaten Sorong Provinsi Papua Barat. Jurnal Kebijakan Kesehatan Indonesia. Vol 4 (2)

[5] Puadi, A., Qomarudin, M. (2016). Role Of Aids Prevention And Control Commission In East Kotawaringin. Jurnal Promkes. Vol 4(2).

[6] Zainal,S. (2018). Advocacy Implementation, Communication, Social Mobilization In The Health Development Program [A Theoretical Review. Jurnal PERSPEKTIF Komunikasi. Vol 1(3) 